University of Nebraska - Lincoln

DigitalCommons@University of Nebraska - Lincoln

\title{
Genetic modification of lignin concentration affects fitness of perennial herbaceous plants
}

\author{
M. D. Casler \\ University of Wisconsin, michael.casler@ars.usda.gov \\ D. R. Buxton \\ USDA-ARS
}

Kenneth P. Vogel

University of Nebraska-Lincoln, kvogel1@unl.edu

Follow this and additional works at: https://digitalcommons.unl.edu/usdaarsfacpub

Casler, M. D.; Buxton, D. R.; and Vogel, Kenneth P., "Genetic modification of lignin concentration affects fitness of perennial herbaceous plants" (2002). Publications from USDA-ARS / UNL Faculty. 1937. https://digitalcommons.unl.edu/usdaarsfacpub/1937

This Article is brought to you for free and open access by the U.S. Department of Agriculture: Agricultural Research Service, Lincoln, Nebraska at DigitalCommons@University of Nebraska - Lincoln. It has been accepted for inclusion in Publications from USDA-ARS / UNL Faculty by an authorized administrator of DigitalCommons@University of Nebraska - Lincoln. 


\section{M.D. Casler · D.R. Buxton · K.P. Vogel}

\section{Genetic modification of lignin concentration affects fitness of perennial herbaceous plants}

Received: 12 December 2000 / Accepted: 27 February 2001

\begin{abstract}
Populations of four perennial herbaceous species that were genetically modified for altered lignin content (or associated forage digestibility) by conventional plant breeding were evaluated for two agricultural fitness traits, plant survival and plant biomass, in three Northcentral USA environments for more than 4 years. Reduced lignin concentration or increased digestibility resulted in increased winter mortality in two of four species and reduced biomass in one species. Results from other experiment indicate that these apparent genetic correlations may be ephemeral, suggesting that selection for fitness can be successful within high-digestibility or low-lignin germplasm. Results indicate that perennial plants genetically engineered with altered lignin concentration or composition for use in livestock, pulp and paper, or bioenergy production should be evaluated for fitness in field environments prior to use in agriculture.
\end{abstract}

Keywords Lignin $\cdot$ Digestibility $\cdot$ Selection $\cdot$ Breeding $\cdot$ Fitness $\cdot$ Cold tolerance

\section{Introduction}

After cellulose, lignin is the second most-abundant natural polymer on earth. Lignin is present in all terrestrial higher plants including herbaceous perennials. It is in-

Communicated by H.C. Becker

M.D. Casler (区)

Department of Agronomy, University of Wisconsin, Madison,

WI 53706-1597, USA

e-mail: mdcasler@facstaff.wisc.edu

D.R. Buxton

USDA-ARS, Beltsville Agricultural Research Center, Beltsville, MD 20705-2350, USA (formerly USDA-ARS,

U.S. Dairy Forage Research Center Clusters, Ames, IA 50010, USA)

K.P. Vogel

USDA-ARS, University of Nebraska, Lincoln, NE 68583-0937, USA volved in structural support, anti-herbivory, and wound response. Commercial utilization of numerous plant products is severely hampered by lignin, including the production of paper from pulpwood which must be chemically de-lignified. Lignification of herbaceous crops limits the amount of digestible energy available to livestock, resulting in incomplete utilization of cellulose and hemicellulose by ruminant animals. Genetic reductions in the lignin concentration of forages can increase the availability of energy from cell-wall polysaccharides, improving the efficiency of livestock production (Casler and Vogel 1999).

Lignin is synthesized from monolignols produced in the shikimic acid pathway (Sewalt et al. 1997; Osakabe et al. 1999). Recent research with transgenic plants has demonstrated that lignin is a highly plastic compound, synthesized by a metabolic grid that results in a wide array of biochemical phenotypes (Boudet and GrimaPettenati 1996; Ralph et al. 1997; Jung and Ni 1998; Ralph et al. 1998). This metabolic grid results in considerable flexibility and plasticity to the lignification process, due to numerous potential sites at which genetic modification may occur, either naturally or with transgenes (Lee et al. 1997; Piquemal et al. 1998).

Antisense transgene constructs are available, or are rapidly being developed, for all enzymes in the phenylpropanoid pathway (Lee et al. 1997; Sewalt et al. 1997) and are being utilized to determine their effect on plant lignin concentration and composition. In transgenic tobacco (Nicotiana tabacum L.) some abnormal growth and development has occurred when transgenic plants exhibited significant reductions in lignin content (Lee et al. 1997; Jung and Ni 1998). However, both the lignin composition and content of some Arabidopsis (Arabidopsis thaliana Heynh.) and tobacco anti-sense lines (Lee et al. 1997; Jung and Ni 1998; Piquemal et al. 1998; Ralph et al. 1998), and the lignin content of aspen, Populus tremuloides Michx. (Hu et al. 1999), were significantly changed without apparent adverse effects on transgenic plants.

Much of the genetic variation that has been generated in typical novel-lignin transgenic plants is parallel to that 
observed in natural populations of non-transgenic plants including variation in lignin concentration and composition. Many novel-lignin transgenic events appear to mimic natural genetic polymorphisms, including the brown-midrib mutants of maize (Zea mays L.) and other annual cereals (Cherney et al. 1991; Boudet and GrimaPettenati 1996; Lee et al. 1997; Sewalt et al. 1997; Piquemal et al. 1998; Casler and Jung 1999) and quantitative trait loci in natural populations (Casler and Jung 1999). Phenotypic changes in transgenic plants, including changes in lignin concentration and composition and the reddish-brown coloration of some low-lignin plants, are both qualitatively and quantitatively similar to natural variation for these traits (Casler 2000). Furthermore, the relative increases observed in in vitro digestibility are similar regardless of whether lignin is modified by conventional selection, mutagenesis, or transformation (Casler 2000). Indeed, transgene technology has shown that two of the brown-midrib mutants of maize, which typically reduce lignin concentration by 10 to $20 \%$ and give a reddish-brown color to lignified tissue, represent lesions to key enzymes in the phenylpropanoid pathway (Vignols et al. 1995; Halpin et al. 1998).

Genetic modifications to lignin concentration and/or composition would be economically important in many woody or herbaceous perennials. However, the brownmidrib genes of annual cereals uniformly reduce agricultural fitness by reducing both grain and biomass yield (Barrière and Argillier 1993; Barrière et al. 1988). The purpose of the present research was to test the hypothesis that a genetic relationship exists between lignin concentration (or digestibility) and agricultural fitness of perennial herbaceous plants by using populations of plants from four herbaceous perennial species divergently selected for lignin concentration or in vitro dry matter digestibility (IVDMD). Because of the parallel nature of phenotypic variation between novel-transgenics and natural mutations influencing lignin, this work should serve as a model for novel-lignin transgenic research.

\section{Materials and methods}

Divergent selection for IVDMD was practiced in I79-OGP-DT orchardgrass, Dactylis glomerata L. (Rind and Carlson 1988; Rind Baloch 1989); WB8 smooth bromegrass, Bromus inermis Leyss. (Ehlke et al. 1986); and 'Pathfinder' switchgrass, Panicum virgatum L. (Hopkins et al. 1995a). Divergent selection for acid-detergent lignin concentration was conducted in 'Saranac-AR' alfalfa, Medicago sativa L. (Kephart et al. 1990). One cycle of phenotypic selection, with intercrossing, was practiced in each direction for each species. Two additional cycles of selection were conducted for high IVDMD in switchgrass $(\mathrm{C}+2$ and $\mathrm{C}+3)$. All base populations will be referred to as $\mathrm{C} 0$, and cycle-1 populations as $\mathrm{C}-1$ (low IVDMD or high lignin) or $\mathrm{C}+1$ (high IVDMD or low lignin).

Seedlings of all populations (except for $\mathrm{C} 0$ alfalfa and $\mathrm{C}+2$ switchgrass for which seed was unavailable) were established in a glasshouse in February 1992 and transplanted to field plots in May 1992. Field sites and soil types were: Ames, Iowa [Nicollet loam (fine-loamy, mixed, mesic Aquic Hapludolls)]; Mead, Neb. [Sharpsburg silt loam (fine, montmorillonitic, mesic Typic Argiudolls)]; and Arlington, Wis. [Plano silt loam (fine-silty, mixed, mesic Typic Argiudolls)]. The experimental design for each spe- cies was a randomized complete block with four replicates. Each plot contained 60 plants of one population with plants spaced 1.2$\mathrm{m}$ apart (switchgrass), 0.9-m apart (smooth bromegrass), or 0.6-m apart (orchardgrass and alfalfa).

Plants were harvested two (switchgrass and smooth bromegrass) or three (alfalfa and orchardgrass) times per year in 1993-95. Alfalfa and orchardgrass harvests occurred in May, July, and September. Smooth bromegrass harvests occurred in June and October. Switchgrass harvests occurred in July and October. Smooth bromegrass, orchardgrass, and switchgrass plots were fertilized with $80 \mathrm{~kg}$ of $\mathrm{N} \mathrm{ha}^{-1}$ at the beginning of each growth cycle. All plots were fertilized with $\mathrm{P}$ and $\mathrm{K}$ as suggested by soil-test results. Weeds were controlled for the duration of the experiment by pre-emergence herbicide applications in early spring (as described by Falkner and Casler 1998), rototilling, and hand weeding.

Biomass was determined in 1993 and 1994 by harvesting all herbage above a 9-cm height; adjustment to a dry matter basis was made using dried 500-g herbage samples. Survival percentage of each plot was determined by scoring plants as being alive or dead in early spring, mid-summer, and late autumn, beginning in midsummer 1992 and ending in May or June 1996.

Season total biomass and plant survival at each date were analyzed by separate analyses of variance for each species. Years, locations, and blocks were assumed to have random effects and cycles were fixed. Linear contrasts within the analyses of variance were used to determine correlated responses of agricultural fitness traits (biomass and survival) to selection for lignin or IVDMD.

\section{Results and discussion}

Previous studies have demonstrated that divergent selection for IVDMD or lignin concentration was successful in all four species, summarized in Fig. 1. In smooth bromegrass and switchgrass, selection for IVDMD was associated with an opposite response in lignin concentration $(-7.1$ and -5.9 , respectively, unit change in IVDMD for each unit change in lignin). In alfalfa, selection for lignin concentration was associated with an opposite response in IVDMD $(-0.9$ unit change in IVDMD for each unit change in lignin). Selection responses for lignin and IVDMD were consistent across multiple environments for all four species, indicating that these genetic changes were highly stable and repeatable. Although lignin data for orchardgrass were unavailable, the negative relationship between lignin concentration and IVDMD appears to transcend morphological, physiological, and taxonomic boundaries. Nevertheless, lignin had a greater effect on IVDMD for both grass species than for alfalfa.

Most alfalfa plants died during the 49-month duration of the experiment (Fig. 2). Mortality rates varied among locations, but the end result was similar for all three locations: with less than $10 \%$ survival after 49 months. Approximately $81 \%$ of alfalfa mortality occurred during the winter months; most of the non-winter mortality occurred at Iowa in 1993, months 12 to 17 , and at Wiscon$\sin$ in 1994, months 24 to 28 . Thus, winter stress factors (extended freezing temperatures, reduced light from extended snow cover, ice sheet formation, dessication, and freeze/thaw cycles) were either the primary determinants or the final contributing factor for most alfalfa plant mortality. There was relatively little mortality of orchardgrass and smooth bromegrass, with 10 and $4 \%$ losses overall. Most of the orchardgrass mortality oc- 


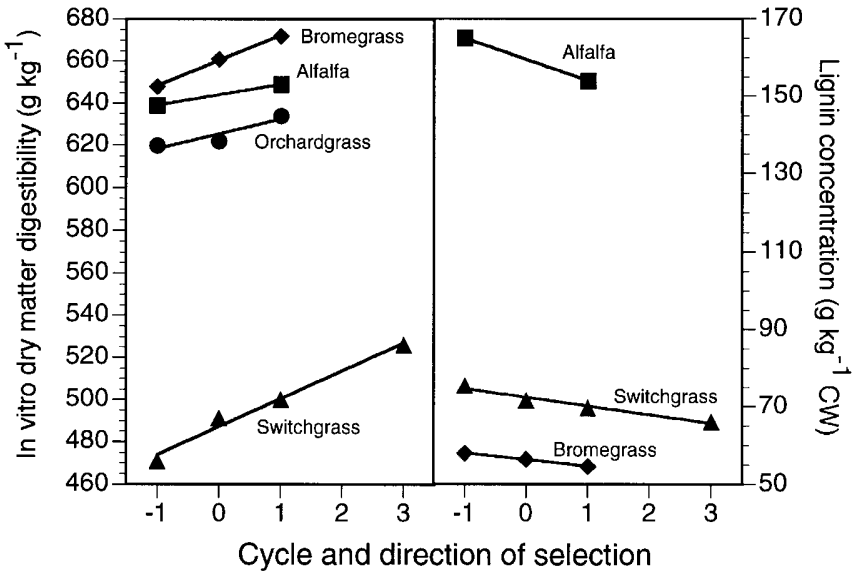

Fig. 1 Phenotypes of populations selected for divergent levels of in vitro dry matter digestibility (IVDMD) or lignin concentration, expressed as a proportion of the cell wall, $C W$ (Casler and Jung 1999). Each cycle of selection represents identification of parents with either high IVDMD (+1), low IVDMD (-1), low lignin $(+1)$, or high lignin $(-1)$, followed by intercrossing and evaluation of progeny. Cycle 0 represents the original population. All responses were significant at $P<0.05$. Alfalfa data are means across three environments (Kephart et al 1990), smooth bromegrass data are means across four environments (Casler and Ehlke 1986; Ehlke et al 1986; Casler and Carpenter 1989), orchardgrass data are means across five environments (Rind and Carlson 1988; Rind Baloch 1989), and switchgrass data are means across eight environments (Hopkins et al 1995a, b). Lignin data were not available for the orchardgrass populations. The cycle 2 high-IVDMD switchgrass selection and the $\mathrm{C} 0$ alfalfa population were not available for evaluation.

curred during the first winter. Apparent increases in survival of smooth bromegrass after 13 months at Nebraska were due to rototilling; smooth bromegrass rhizomes from highly rhizomatous plants were inadvertently chopped and transplanted by rototilling along the edge of spaces left by dead plants. Mortality of switchgrass proceeded slowly until winter 1995/96 when significant mortality occurred at Nebraska and Wisconsin. All switchgrass mortality occurred during the winter months.

The two species with the most-extreme survival percentages, alfalfa and smooth bromegrass, showed no evidence of differences among selected populations, for either biomass or plant survival. Thus, in these two species, there was no evidence for a genetic relationship between lignin concentration and agronomic fitness, despite the two species' inherent differences in plant survival (Fig. 2).

The high-lignin vs low-lignin alfalfa populations had previously shown a mean survival of 64 vs 34\%, respectively, after 2 years in the field at Ames, Iowa (Buxton and Casler 1993). The high-lignin and low-lignin alfalfa populations grown in our experiment represented the progeny of survivors from the respective populations in the Ames, Iowa experiment (Buxton and Casler 1993). Thus, selection for survival following severe winter conditions, using traditional plant breeding procedures, eliminated this observed difference in plant survival be-

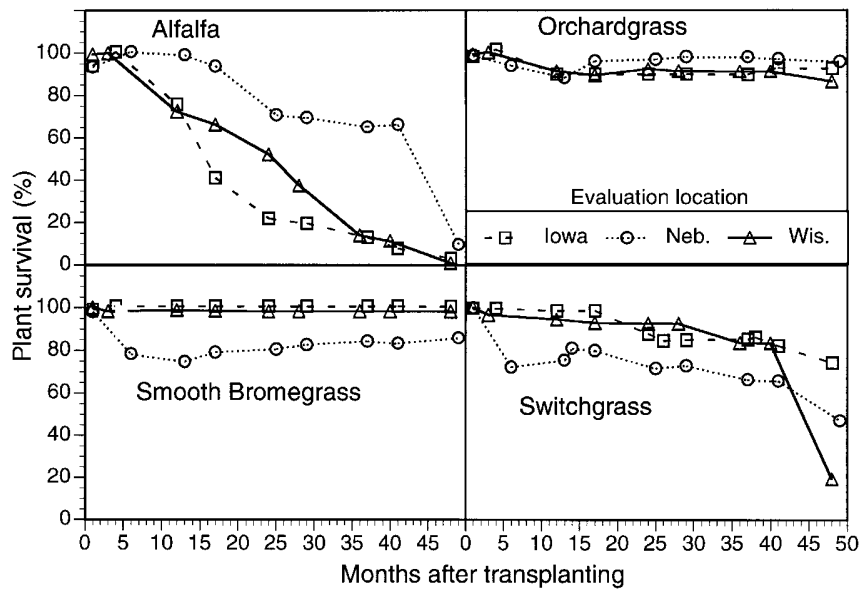

Fig. 2 Survival of transplants during 49 months at three locations. Data points represent means across four replicates and two to four populations per species. Least significant differences for comparisons among dates within locations are: $5.6 \%$ for alfalfa, $2.2 \%$ for orchardgrass, $2.7 \%$ for smooth bromegrass, and $3.7 \%$ for switchgrass

tween high-lignin and low-lignin alfalfa populations. We do not know if lignin concentration was altered by selection for survival, reflecting a genetic correlation between lignin and plant survival, or if lignin remained constant, reflecting more-or-less random segregation of loci controlling these two traits.

Unlike alfalfa, smooth bromegrass is remarkably tolerant of the environmental stresses that occur in this geographic region, persisting indefinitely under most conditions. This high level of inherent stress tolerance appears to be conditioned by factors unrelated to lignification. Furthermore, there appeared to be little or no genetic variation in this smooth bromegrass population for tolerance to the stresses present during this experiment. The results for smooth bromegrass agree with previous results (Casler and Ehlke 1986).

Analyses of variance for orchardgrass revealed significant $(P<0.05)$ linear responses of plant survival measured at three dates: Sept. 1992, Oct. 1993, and May 1996. These responses were consistent across locations, as indicated by non-significant cyclexlocation interactions for all dates. Biomass did not differ among orchardgrass selections. Analyses of variance for switchgrass revealed highly significant $(P<0.01)$ linear responses of plant survival for all dates beginning June 1993. These responses were consistent across locations, as indicated by non-significant cyclexlocation interactions for all dates. Biomass differed among switchgrass selections $(P<0.01)$ and these differences were consistent across both locations and years.

For orchardgrass, a relationship between plant survival and divergent selection for IVDMD was observed as early as autumn of the year of transplanting, despite an average of only $1.5 \%$ mortality during summer 1992 (Fig. 3). This relationship became stronger with time, with the effect doubling by autumn 1993 and doubling 


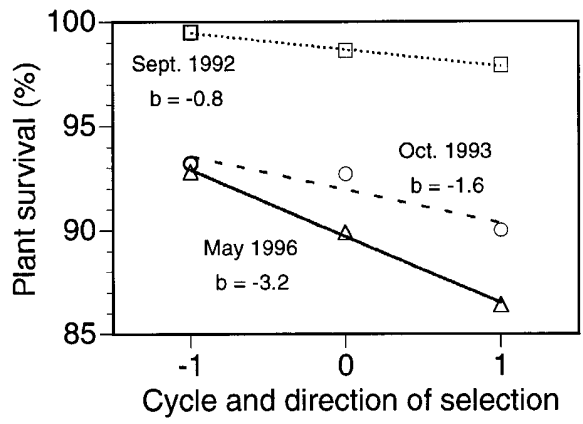

Fig. 3 Agronomic fitness of divergent-IVDMD orchardgrass selections approximately 4, 17, and 48 months after transplanting. Each cycle of selection represents identification of parents with either high $(+1)$ or low $(-1)$ IVDMD, followed by intercrossing and evaluation of progeny. Cycle 0 represents the original population. Each data point represents a mean across four replicates and three locations. Regressions had $\mathrm{R}^{2}=1.00,0.85$ and 1.00 , and $P=0.04$, 0.05 and <0.01, for Sept. 1992, Oct. 1993, and May 1996, respectively

again by the conclusion of the experiment in spring 1996. The minimum plant survival of high-IVDMD orchardgrass was $87 \%$ (Fig. 3). Such a small difference may have little practical significance for sward plots where plants are able to compete against each other and those with the greatest fitness will survive. However, if these data reveal a true genetic relationship between IVDMD and plant survival, then natural selection for survival in swards will reduce the fitness of high-IVDMD plants, gradually reducing the digestibility of an orchardgrass-dominated sward. A similar phenomenon has been observed in smooth bromegrass, for which plants that survived 9-years of intensive grazing were less palatable than their original (unselected) siblings (Falkner and Casler 2000). Furthermore, the progression of the linear relationship of plant survival on cycle number (Fig. 3) suggests that the high-IVDMD orchardgrass population will continue to suffer greater mortality as plants age, until all survivors have a fitness level necessary to survive the local environment. It is currently impossible to predict the survival level at this threshold or if such a threshold exists. In environments where such a threshold does not exist, these data suggest that the high-IVDMD orchardgrass population will eventually reach $100 \%$ mortality more rapidly than the base population or the low-IVDMD population.

In switchgrass, a relationship between plant survival and divergent selection for IVDMD was observed beginning in June 1993 (Fig. 4). As with the orchardgrass populations, the mortality response to selection doubled in the next year and doubled again by the conclusion of the experiment. All switchgrass mortality occurred during winter months. Above-ground biomass of switchgrass also declined due to selection for increased IVDMD (Fig. 4). Because biomass was computed only for living plants and adjusted to a per-plant mean, responses in biomass were not due to responses in plant survival per se. Selection for increased IVDMD in switchgrass

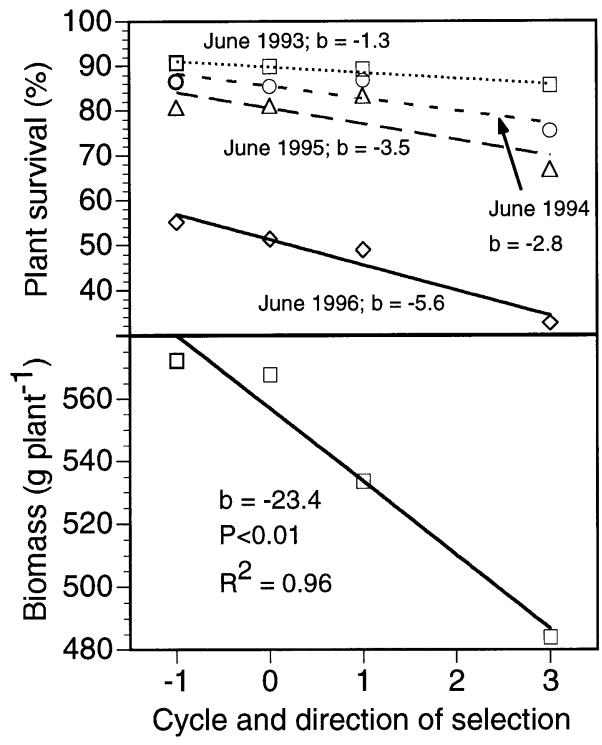

Fig. 4 Agronomic fitness of divergent-IVDMD switchgrass selections, measured as survival approximately 12, 24, 36 and 48 months after transplanting, or 2-year mean biomass. Each cycle of selection represents identification of parents with either high or low IVDMD, followed by intercrossing and evaluation of progeny. Cycle 0 represents the original population. Each data point represents a mean across four replicates and three locations. Plant-survival regressions had $\mathrm{R}^{2}=0.94,0.75,0.64$ and 0.94 for June 1993 , 1994, 1995 and 1996, respectively. All linear responses had $P<0.01$

apparently decreased both cold tolerance and growth rate (ability to accumulate biomass in a given time period).

Genetic differences in winter mortality of the highand low-lignin alfalfa populations in a previous experiment and the high- vs low-IVDMD orchardgrass and switchgrass populations in this experiment are indicative of genetic correlations of lignin or IVDMD with traits affecting winter survival. These genetic correlations are most likely due to two phenomena: (1) linkage between genes controlling lignin synthesis and genes controlling winter survival traits, (2) pleiotropic effects of individual genes, or (3) a combination of both. Because genes that are closely linked require many generations of random mating to reach linkage equilibrium, it is often impossible to conclusively distinguish between linkage and pleiotropy. Abnormal growth including a weakened vascular systems in transgenic plants with modified lignin concentration (Lee et al. 1997; Jung and Ni 1998) and the reduced biomass yield of brown-midrib mutants of cereals (Cherney et al. 1991; Barrière and Argillier 1993; Jung and Deetz 1993) argue that pleiotropic effects may be involved in other fitness reductions associated with reduced lignin concentration. Because winter survival and lignin synthesis are both affected by an array of genes, it is likely that both pleiotropy and linkage are involved in the observed negative relationships between winter survival and lignin concentration.

In a recently completed study, co-author Vogel (unpublished data, 2000) has demonstrated significant ge- 
netic variation in the high IVDMD cycle-3 switchgrass population $(\mathrm{C}+3)$ for both winter survival and IVDMD, and a non-significant phenotypic correlation between these two traits. This suggests that the relationship between winter survival and lignin or IVDMD is not absolute and can be genetically moderated by selection and recombination. The results of this study, however, clearly demonstrate that genetic modification of perennial plants for reduced lignin, using either conventional breeding procedures or plant transformation, can have significant and immediate negative effects on agricultural fitness. Plants genetically modified for reduced lignin must be evaluated for fitness in multiple environments that include an array of physiological stress factors. Selection among novel-lignin transgenics and their progenies may be required to ensure adequate agricultural fitness. Recurrent selection strategies for increased IVDMD or reduced lignin should include field testing of plants to ensure that fitness is retained throughout the selection process.

\section{References}

Barrière Y, Argillier O (1993) Brown-midrib genes of maize: a review. Agronomie 13:865-876

Barrière Y, Gallais A, Berthet H (1988) Utilisation du gène brown midrib-3 pour l'amélioration du ma fourrage. II. Sélection récurrente de populations. Agronomie 8:625-631

Boudet AM, Grima-Pettenati J (1996) Lignin genetic engineering. Mol Breed 2:25-39

Buxton DR, Casler MD (1993) Environmental and genetic factors affecting cell wall composition and digestibility. In: Jung HG et al. (eds) Forage cell wall structure and digestibility. American Society of Agronomy, Madison, Wisconsin, pp 685-714

Casler MD (2000) Breeding forage crops for increased nutritional value. Advan Agron 51:51-107

Casler MD, Carpenter JA (1989) Morphological and chemical responses to selection for in vitro dry matter digestibility in smooth bromegrass. Crop Sci 29:924-928

Casler MD, Ehlke NJ (1986) Forage yield and yield component changes with divergent selection for in vitro dry matter digestibility of smooth bromegrass. Crop Sci 26:478-481

Casler MD, Jung HG (1999) Selection and evaluation of smooth bromegrass clones with divergent lignin or etherified ferulic acid concentration. Crop Sci 39:1866-1873

Casler MD, Vogel KP (1999) Accomplishments and impact from breeding for increased forage nutritional value. Crop Sci 39: $12-20$

Cherney JH, Cherney DJR, Akin DE, Axtell JD (1991) Potential of brown-midrib, low-lignin mutants for improving forage quality. Advan Agron 46:157-198

Ehlke NJ, Casler MD, Drolsom PN, Shenk JS (1986) Divergent selection for in vitro dry matter digestibility in smooth bromegrass. Crop Sci 26:1123-1126

Falkner LK, Casler MD (1998) Preference for smooth bromegrass clones is affected by divergent selection for nutritive value. Crop Sci 38:690-695
Falkner LK, Casler MD (2000) Genetic shifts in smooth bromegrass under grazing: changes in nutritional value and preference for surviving vs original genotypes. Grass Forage Sci 55:351-360

Halpin C, Holt K, Chojecki J, Oliver D, Chabbert B, Monties B, Edwards K, Barakate A, Foxon GA (1998) Brown-midrib maize (bm1) - a mutation affecting the cinnamyl alcohol dehydrogenase gene. Plant J 14:545-553

Hopkins AA, Vogel KP, Moore KJ (1995a) Predicted and realized gains from selection for in vitro dry matter digestibility and forage yield in switchgrass. Crop Sci 35:253-258

Hopkins AA, Vogel KP, Moore KJ, Johnson KD, Carlson IT (1995b) Genotypic variability and genotypexenvironment interactions among switchgrass accessions from the midwestern USA. Crop Sci 35:565-571

Hu WJ, Harding SA, Lung J, Popko JL, Ralph J, Stokke DD, Tsai CJ, Chiang VL (1999) Repression of lignin biosynthesis promotes cellulose accumulation and growth in transgenic trees. Nature Biotech 17:808-812

Jung HG, Deetz DA (1993) Cell wall lignification and degradability. In: Jung HG et al. (eds) Forage cell wall structure and digestibility. American Society of Agronomy, Madison, Wisconsin, pp 315-346

Jung HG, Ni W (1998) Lignification of plant cell walls: impact of genetic manipulation. Proc Natl Acad Sci USA 95:1274212743

Kephart KD, Buxton DR, Hill RR Jr (1990) Digestibility and cellwall components of alfalfa following selection for divergent herbage lignin concentration. Crop Sci 30:207-212

Lee K, Meyer K, Chapple C, Douglas CJ (1997) Antisense suppression of 4-coumarate:coenzyme A ligase activity in Arabidopsis leads to altered lignin subunit composition. Plant Cell 9:1985-1998

Osakabe K, Tsao CC, Li LG, Popko JL, Umezawa T, Carraway DT, Smeltzer RH, Joshi CP, Chiang VL (1999) Coniferyl aldehyde 5-hydroxylation and methylation direct syringyl lignin biosynthesis in angiosperms. Proc Natl Acad Sci USA 96:8955-8960

Piquemal J, Lapierre C, Myton K, O'Connell A, Schuch W, Grima-Pettenati J, Boudet AM (1998) Down-regulation of cinnamyl-CoA reductase induces significant changes of lignin profiles in transgenic tobacco plants. Plant J 13:71-83

Ralph J, MacKay JJ, Hatfield RD, O'Mallory DM, Whetten RW, Sederoff RR (1997) Abnormal lignin in a loblolly pine mutant. Science 277:235-239

Ralph J, Hatfield RD, Piquemal J, Yahiaoui N, Pean N, Lapierre C, Boudet AM (1998) NMR characterization of altered lignins extracted from tobacco plants down-regulated for lignification enzymes CAD and CCR. Proc Natl Acad Sci USA 95:12803-12808

Rind Baloch MJ (1989) Bidirectional selection for dry matter digestibility in orchardgrass. PhD Dissertation, Iowa State University, Ames, Iowa

Rind MJ, and Carlson IT (1988) Bidirectional greenhouse selection for dry matter digestibility in orchardgrass. In: Agronomy Abstracts. Am Soc Agron, Madison, Wisconsin, p 94

Sewalt VJH, Ni W, Jung HG, Dixon RA (1997) Lignin impact on fiber degradation: increased enzymatic digestibility of genetically engineered tobacco (Nicotiana tabacum) stems reduced in lignin content. J Agric Food Chem 45:1977-1983

Vignols F, Rigau J, Torres MA, Capellades M, Puigdomenech P (1995) The brown midrib3 (bmr3) mutation in maize occurs in the gene encoding caffeic acid O-methyltransferase. Plant Cell $7: 407-416$ 